This is a peer-reviewed, accepted author manuscript of the following research article: De Francesco, F., Leopold, L., \& Tosun, J. (2020). Distinguishing policy surveillance from policy tracking: transnational municipal networks in climate and energy governance. Journal of Environmental Policy \& Planning. https://doi.org/10.1080/1523908X.2020.1785280

\title{
Distinguishing policy surveillance from policy tracking: transnational municipal networks in climate and energy governance
}

The challenges related to climate change and energy issues have induced a growing number of actors to participate in governance arrangements of information-sharing and mutual policy-learning. In recent years the increasing availability of data on policy outputs and outcomes has enabled researchers to observe variation in these governance arrangements of transnational municipal climate networks (TMCNs). To capture this variation, we rely on two ideal types of policy information systems: policy tracking (PT) and policy surveillance (PS). Focusing on two TMCNs active in energy governance, our qualitative analysis attests the existence of these two modes of monitoring and reporting greenhouse gas emissions. The Covenant of Mayors for Climate \& Energy exemplifies how PS schemes can standardize scoring methodology and facilitate policy compliance and enforcement. In contrast, Energy Cities fits the typology of a PT system that aims to showcase local initiatives and mutual learning.

Keywords: climate change; energy; policy surveillance; policy tracking; soft governance. 
This is a peer-reviewed, accepted author manuscript of the following research article: De Francesco, F., Leopold, L., \& Tosun, J. (2020). Distinguishing policy surveillance from policy tracking: transnational municipal networks in climate and energy governance. Journal of Environmental Policy \& Planning. https://doi.org/10.1080/1523908X.2020.1785280

\section{Introduction}

Policy surveillance (PS) ensures the effectiveness of international cooperation for solving transboundary issues. For instance, the Paris Agreement requires assessments of the extent to which political leaders have fulfilled their pledge to keep climate change below $2^{\circ} \mathrm{C}$. Countries' efforts to reduce greenhouse gas (GHG) emissions are monitored through regular reports. To ensure compliance, the EU has embraced monitoring and reporting of GHG emissions by relying on PS (Ringel \& Knodt, 2018; Schoenefeld, Hildén, \& Jordan, 2018; Schoenefeld \& Jordan, 2020).

PS is an information-creation mechanism that emerged in the context of environmental negotiations, which are typically characterized by strong free-riding incentives (Aldy \& Pizer, 2016). Through reputational recognition or damage, PS has the potential to enhance the transparency of international cooperation and compliance with international agreements (Aldy, 2014). Indeed, country reviews, benchmarks, performance indicator scores, and public registers allow the identification and disclosure of a nation's progress towards environmental policy targets (Esty \& Karpilow, 2019; Terman \& Voeten, 2018).

These mechanisms for monitoring and reporting domestic policy actions have also been established in other forms of international cooperation, e.g. in transnational municipal climate networks (TMCNs). Consisting of cities located in different jurisdictions, TMCNs promote collaboration on climate change adaptation and mitigation. They mostly rely on voluntary mechanisms for disseminating research and policy analysis, setting and monitoring targets, planning and funding projects, and lobbying (Lee \& Jung, 2018). For local-level actors that lack the necessary competences for adopting legislation beyond their territories, TMCNs serve as a venue for advocating 
This is a peer-reviewed, accepted author manuscript of the following research article: De Francesco, F., Leopold, L., \& Tosun, J. (2020). Distinguishing policy surveillance from policy tracking: transnational municipal networks in climate and energy governance. Journal of Environmental Policy \& Planning. https://doi.org/10.1080/1523908X.2020.1785280

more ambitious climate actions than the ones agreed to at the international and national levels (van der Heijden, 2018).

TMCNs proffer not only alternative policy programmes but also alternative modes of accountability in networked climate governance (Gordon, 2016). Much like the EU, some TMCNs have also started carry out more rigourous policy-monitoring activities (Gordon, 2016; Knodt \& Schoenefeld, 2020; Ringel \& Knodt, 2018). Since voluntary transnational cooperation can take different forms, this study focuses on understanding the variation in monitoring and reporting activities carried out by TMCNs (Knodt, Ringel, \& Müller, 2020). We maintain that the surveillance systems of TMNCs can provide useful lessons for enhancing international and European policy cooperation in governing climate and energy issues. Indeed, based on shared ideas and public demands, TMCNs are characterized by a voluntary logic of action for adopting practices of transparency and disclosure. In the absence of formal coercive authority, they secure the compliance of cities by 'ordering without giving orders' (Gordon, 2016, pp. 91-93).

How can we explain the choice of TMCNs to establish PS schemes? To answer this question, we rely on two ideal types of information and monitoring systems for assessing the progress of cities towards energy decarbonization: policy tracking (PT) and PS. The latter is based on reporting requirements and accurate and transparent benchmarking of cities across time. Instead of relying on the showcasing of cities' experiences with climate and energy actions as it is the case with PT, PS facilitates the introduction of naming-and-shaming devices and disciplinary sanctions in order to tarnish the reputation of non-compliant constituents.

We compared two similar, state-led TMCNs (i.e., the Covenant of Mayors and Energy Cities) that mainly operate in Europe and are funded by EU institutions. The 
This is a peer-reviewed, accepted author manuscript of the following research article: De Francesco, F., Leopold, L., \& Tosun, J. (2020). Distinguishing policy surveillance from policy tracking: transnational municipal networks in climate and energy governance. Journal of Environmental Policy \& Planning. https://doi.org/10.1080/1523908X.2020.1785280

qualitative analysis shows that the difference in the type of information and monitoring systems is due to their organisational and functional settings.

In the next section, we first provide information on the evolution and features of TMCNs in governing climate change and energy. Then, we propose a framework for differentiating the information and monitoring systems of TMCNs. We test the proposed analytical framework on the two selected TMCNs in order to understand how they differ in their hard vs soft forms of policy monitoring and reporting. Finally, we discuss our findings more broadly in light of the research agenda set by this Special Issue.

\section{TMCNs and climate policy experimentation}

For many years, studies on climate politics adopted the perspective of international relations as the topic represents a classic collective action problem. Besides international and regional cooperation on climate issues, there is a growing recognition of subnational levels and cities in particular as dynamic sites of governance innovation (see, e.g., Jordan et al., 2015; Wolfram, van der Heijden, Juhola, \& Patterson, 2019). To tackle environmental issues, cities in Europe and North America started to form transnational networks in the 1980s. While initially their geographic focus was limited, membership in those networks expanded to other world regions during the 1990s. Today, most city networks have members from different continents, though several networks, such as Clean Air Asia, have maintained their respective geographic focus (see Tosun \& Leopold, 2019).

In global climate governance, TMCNs are characterized by different functional purposes. They can experiment with policies and programmes as well as engage in lobbying at the regional, national and international levels (see Lee \& Jung, 2018). 
This is a peer-reviewed, accepted author manuscript of the following research article: De Francesco, F., Leopold, L., \& Tosun, J. (2020). Distinguishing policy surveillance from policy tracking: transnational municipal networks in climate and energy governance. Journal of Environmental Policy \& Planning. https://doi.org/10.1080/1523908X.2020.1785280

Another way to discern this functional difference is by referring to 'municipal voluntarism'. This functional category characterised the first generation of TMCNs but is increasingly being replaced by 'strategic urbanism' (Bulkeley \& Betsill, 2013, pp. 139140). Whereas municipal voluntarism aims at stimulating mutual learning by disseminating experience, with strategic urbanism the functional focus of city networks, such as C40 Cities Climate Leadership Group, is to represent local authorities in national and international politics (van der Heijden, 2018, p. 89).

These functions are, however, complementary. Cities and communities are still regarded as sites for designing and implementing climate policy experiments (Bansard, Pattberg, \& Widerberg, 2017). TMCNs provide information, carry out research, and participate in consultation and planning processes (see, e.g., Nagorny-Koring, 2018; Tosun \& Leopold, 2019). This aspect of experimentation is relevant for comparing and drawing lessons on transnational governance arrangements. Regardless of whether a network is a manifestation of municipal voluntarism or strategic urbanism, an information and monitoring system is necessary for sharing information among transnational networks and achieving policy coordination across sectors and political levels.

By examining elements of policy monitoring and disclosure systems that generate and analyze information on GHG mitigation policies, we contrast PS systems (Aldy, 2014) with other evaluation systems that aim to disseminate good practice (Chriqui, O'Connor, \& Chaloupka, 2011). Climate change mitigation policies here include the promotion of renewable energy and energy efficiency, which makes this definition appropriate for our interest in the governance of climate change and energy. Conducting comparative assessments of policy monitoring systems allows us to assess the variation rigourousness of accountability mechanisms within international climate and energy 
This is a peer-reviewed, accepted author manuscript of the following research article: De Francesco, F., Leopold, L., \& Tosun, J. (2020). Distinguishing policy surveillance from policy tracking: transnational municipal networks in climate and energy governance. Journal of Environmental Policy \& Planning. https://doi.org/10.1080/1523908X.2020.1785280 governance (Gordon, 2016). This type of comparative analysis is not novel, since it aims to draw lessons on effective compliance in international environmental policy (Aldy, 2014). However, assessing the functional variation of TMCNs facilitates the comparison of modes of transnational cooperation, which in turn may reveal different means of achieving transparency and effectiveness within policy monitoring systems. Indeed, the different functional purposes of TMCNs (see Bulkeley \& Betsill, 2013; Kern, 2018) should be reflected in the overall focus of the policy monitoring and reporting system.

\section{Typologies of TMCNs and policy monitoring arrengements}

Municipal voluntarism requires a consistent flow of information regarding policies adopted and implemented by members of city networks. The careful monitoring of projects and significant changes is a precondition for experimenting and learning from policy innovations. This mode of ongoing, systematic collection and dissemination of information facilitates immediate policy action (see Chriqui et al., 2011). This type, which we refer to as policy monitoring for learning, requires institutional capacity as well as political will and competencies that are rarely present in TMCNs (Bulkeley \& Betsill, 2013). It is more plausible to reason that most networks have been simply collecting data on policy practices in order to establish common discourses, meanings and frames of environmental issues (Fünfgeld, 2015).

With the turn towards strategic urbanism and the politicization of city collaborations has come a transformation of policy monitoring. These networks do not require extensive information on policy measures as their main task is to lobby other political levels. Much like the simplified version of multilateral knowledge exchange in municipal voluntarism networks, the information system associated with advocacy activities identifies and promotes good practice. This type of PT system maps policy 
This is a peer-reviewed, accepted author manuscript of the following research article: De Francesco, F., Leopold, L., \& Tosun, J. (2020). Distinguishing policy surveillance from policy tracking: transnational municipal networks in climate and energy governance. Journal of Environmental Policy \& Planning. https://doi.org/10.1080/1523908X.2020.1785280 interest and action among participating members (see Chriqui et al., 2011). Therefore, we do not expect to find 'harder' elements of soft governance (Knodt \& Schoenefeld, 2020) in these systems as they do not focus on actual policy implementation.

In PS systems, formal commitments and network obligations are central and override the volunteristic approaches of PT systems. PS requires a comprehensive information system for measuring the fulfilment of countries' pledges and the actual impact of cities' policy initiatives, based on transparent and accurate data and tools for comparative data collection. Such an information system allows cities to learn how to achieve their targets. As a harder, more rigorous information system, PS raises the profile of cities in the international policy arena by advocating their own models of policy evaluation and benchmarking.

In the remainder of this section, we describe the distinctive features of each type of information system associated with the different modes of international policy monitoring. Table 1 distinguishes elements of PS from elememts of PT by clarifying several dimensions of their information systems' analytical and evaluative functions. The assessment of these characteristics then guides our qualitative comparison of the use of harder elements of surveillance systems across city networks.

\section{Type of information}

PS systems require systematic and longitudinal data for assessing the extent of compliance with pledges. This information must be even more comprehensive if the network has impact-type pledges in place or aims to examine the impact of compliance on environment and population. Accordingly, quantitative data as produced by PS schemes can be used for naming-and-shaming. Conversely, PT uses qualitative information on policy projects and initiatives adopted by cities. PT systems provide a 
This is a peer-reviewed, accepted author manuscript of the following research article: De Francesco, F., Leopold, L., \& Tosun, J. (2020). Distinguishing policy surveillance from policy tracking: transnational municipal networks in climate and energy governance. Journal of Environmental Policy \& Planning. https://doi.org/10.1080/1523908X.2020.1785280

snapshot of the policies and actions in place, whereas PS measures policy changes and impacts across time (Chriqui \& Eyler, 2016). PT is usually based on descriptive accounts of the quality of policy projects and how they fit with the specific policy objectives established within a given network (Chriqui et al., 2011, p. 23). Therefore, these data are less suitable for exerting pressure on policymakers to implement more ambitious climate policies.

\section{Research versus advocacy orientation}

Given the type of information collected, a PS system is potentially associated with compliance. When a network is based on pledges, a complex dataset is required for establishing a causal relationship between compliance and environmental impact. While collecting such data requires sufficient analytical and procedural capacity (Lee \& Jung, 2018), PS can induce governments to take more effective measures to combat climate change. Conversely, PT systems do not generate information that is suitable for evaluation. It is a system for advertising policy initiatives, and a means for advocacy groups to facilitate the adoption of policies in a given jurisdiction (Chriqui \& Eyler, 2016, p. 292).

\section{Quality and credibility of information}

An effective PS mechanism must produce credible and neutral information and facilitate the analysis of policy actions and outcomes. Consequently, networks with permanent staff are more likely to deliver reliable information and a high-quality evaluation of climate and energy policy due to enhanced competence and independence (Aldy, 2014, p. 282; Lee \& Jung, 2018). Another aspect is the employment of expertise that may help to depoliticize the PS system. Within PT systems, expertise is less influential (Chriqui \& 
This is a peer-reviewed, accepted author manuscript of the following research article: De Francesco, F., Leopold, L., \& Tosun, J. (2020). Distinguishing policy surveillance from policy tracking: transnational municipal networks in climate and energy governance. Journal of Environmental Policy \& Planning. https://doi.org/10.1080/1523908X.2020.1785280

Eyler, 2016), as TMCNs revolve mainly around discovering and sharing good practices (Nagorny-Koring, 2018).

\section{Engagement of peers}

Surveys of PS systems show that compliance is facilitated when members of international cooperation engage in policy review and evaluation (Aldy, 2017, p. 104). For instance, OECD-style peer review (Lehtonen, 2020) can facilitate the common understanding of the objectives and mechanisms of international cooperation. Overall, 'reciprocal multilateral scrutiny' is an important mode of persuasion for ensuring commitment to the fulfilment of pledges (Schelling, 2002). At the administrative capacity level, networks based on PS should establish peer-review procedures. In PT systems, we expect peerreview evaluation to be marginal since the data do not rely on a systematic and continued collection and validation process. If a network concentrates on PT, it will ask its members to engage in activites related to dissemination and the sharing of best practices (NagornyKoring, 2018).

\section{Tools for policy learning}

Policy learning is the updating of individual beliefs in light of experience and social interaction, which influence how policy actors perceive a problem and seek to solve it (Dunlop \& Radaelli, 2013, p. 257). Several instruments can enhance policy learning among members of a TMCN: codes for sharing good policy practice, templates for selfreporting, comparative indicators, and annual progress reports (see, e.g., Bellinson \& Chu, 2019). However, policy instruments vary in the way they enable actors to update their beliefs (Dunlop \& Radaelli, 2018, p. 257). Within PT, best pratices are often simply replicated by other cities and can actually prevent policy learning from taking place 
This is a peer-reviewed, accepted author manuscript of the following research article: De Francesco, F., Leopold, L., \& Tosun, J. (2020). Distinguishing policy surveillance from policy tracking: transnational municipal networks in climate and energy governance. Journal of Environmental Policy \& Planning. https://doi.org/10.1080/1523908X.2020.1785280

(Nagorny-Koring, 2018). Instruments typical of PS are more likely to induce learning processes and result in policy change.

\section{Openness and transparency}

A transparent PS system allows the efforts of participating parties to be compared, demonstrating the aggregate impacts of their actions on the environment. An open PS system that disseminates comparative information on network members can empower stakeholders and members of civil society (Aldy, 2014, pp. 284-285). These elements facilitate the accountability of the international regime and consequently its effectiveness. Accordingly, TMCNs must establish an information system that is open to the public.

Openness and transparency are crucial for ensuring compliance through means of positive recognition or naming and shaming (van Erp, 2011). Between the two information systems, we expect differences in the types of information that are open to the public. In PS, benchmarking and ranking are predominant in the websites of networks, since they enable immediate and easy comparison of the cities' performance. Cities that do not perform well on certain key indicators are clearly named, driving them towards compliance in order to restore their reputation. On the other hand, transparency and access are limited in a PT system to the qualitative data collected on members' activities.

All in all, PS is typical of networks based on policy pledges and targets. It is set up to monitor the members' progress towards their fulfilment. This function can be complemented by a sophisticated information system if evidence is required to assess the impact of international cooperation on the environment. PT, conversely, is based on a simpler information system. It aims to promote climate mitigation through the construction of common knowledge, discourse, and cognitive frames. 
This is a peer-reviewed, accepted author manuscript of the following research article: De Francesco, F., Leopold, L., \& Tosun, J. (2020). Distinguishing policy surveillance from policy tracking: transnational municipal networks in climate and energy governance. Journal of Environmental Policy \& Planning. https://doi.org/10.1080/1523908X.2020.1785280

***Table 1 here***

\section{Theoretical expectations}

Having constructed our analytical framework for comparing the types of information, the extent of transparency and effectiveness of PS and related administrative dimensions, we formulate our main expectation. It is informed by the argument put forth by Lee and Jung (2018), that the way TMCNs monitor depends on their institutional arrangements. While they differentiate between multilateral institution-led cooperation, we offer a more nuanced analysis concentrating on the correspondence between organizational features (i.e., funding sources and functional purposes) and the establishment of PS.

Externally funded TMCNs are likely to have a clear mandate to monitor their members' compliance and therefore to produce comparative assessments of different cities in attaining goals related to climate change and energy. Because this quantification of cities' efforts triggers 'elite shaming' and professional/peer recognition, policy coordination through information sharing and policy evaluation is not merely an administrative and apolitical steering mechanism; it requires a fully independent supporting agency. Indeed, a low level of organizational intertwining with constituent cities strenghten the institutional and administrative capacity necessary for scrutinizing policy pledges. Furthermore, because TMCNs are accountable to the institutions that founded and fund them and/or that are involved in their activities, we expect fully-fledged PS systems when a single dominant stakeholder exists. Conversely, we argue that fully or partly self-funded TMCNs perform similar to multilateral cooperation (Lee \& Jung, 2018). Because the supporting agency depends on membership fees, this type of institution-led network cannot impel their constituents to PS. Thus, we expect self-funded TMCNs to rely on PT, based on qualitative text-based reports on new policy measures 
This is a peer-reviewed, accepted author manuscript of the following research article: De Francesco, F., Leopold, L., \& Tosun, J. (2020). Distinguishing policy surveillance from policy tracking: transnational municipal networks in climate and energy governance. Journal of Environmental Policy \& Planning. https://doi.org/10.1080/1523908X.2020.1785280

that does not allow for the comparative assessment of policy change. Overall, this system revolves around the idea of showcasing the progress and success of policy advocacy, rather than policy benchmarking (Chriqui et al., 2011). This information system is aligned with the function of lobbying, since it transfers its ideas to other networks, governments or IOs. We expect networks established for strategic urbanism to be tracking the practices of their members. Conversely, TMCNs that emerged in the context of international cooperation focusing on policy pledges should be based on PS systems.

\section{Case selection and methodology}

To test the proposed ideal types of city cooperation, we concentrate on two TMCNs that focus on energy and climate change: The Covenant of Mayors for Climate \& Energy $(\mathrm{CoM})$ and Energy Cities (EC). Although these networks share some similarities, they vary regarding their financing. Twenty percent of EC's funding comes from membership fees, another 20 percent from grants from national governments and services delivered to cities, and the remaining 60 percent come from the European Commission, whereas CoM is fully funded by the European Commission. Moreover, EC concentrates on lobbying and research, whereas CoM focuses on target-setting and monitoring (Lee \& Jung, 2018).

The CoM was founded by the European Commission in 2008 to promote adaptation and mitigation on the local level. In 2016, it merged with the Compact of Mayors initiative and has since existed as the European regional branch of the newly established CoM with unchanged provisions in terms of the cities' objectives and participation requirements. Currently, 10,225 cities and local authorities have signed the CoM's letter of intent, committing themselves to either or both of EU's climate change targets for 2020 and 2030 or further adaptation targets. Although the level of communication among the member cities is lower than one would expect from a mutual- 
This is a peer-reviewed, accepted author manuscript of the following research article: De Francesco, F., Leopold, L., \& Tosun, J. (2020). Distinguishing policy surveillance from policy tracking: transnational municipal networks in climate and energy governance. Journal of Environmental Policy \& Planning. https://doi.org/10.1080/1523908X.2020.1785280

learning network, the main approach of the CoM is to mobilize ambitious climate action at the local level through sound action and policy programs. The latter includes standardized measurement and the commitment to pre-specified GHG emission reduction targets. Therefore, the participating cities are obliged to compile an initial action plan for climate change adaptation and to assess baseline emissions and the main risks that climate change poses to them. Although the CoM does not regard itself as a city network, it is a form of institution-led cooperation equivalent to TMCNs (Lee \& Jung, 2018). This speaks in favour of our argument that different organizational settings of city cooperation result from the different tasks these are meant to perform.

At the other end, Energy Cities is a network particularly engaged in consultation activities as evidenced by its contribution to the European Investment Bank's approach to supporting climate action (Energy Cities, 2015). Established in 1990, EC has grown to include nearly 200 members from 30 countries and around 1,000 local communities. Its strategic approach is based on networking, lobbying, and research (Lee \& Jung, 2018, p. 103). Its functional focus is to represent member cities at the European level and international conferences. Moreover, EC disseminates knowledge by showcasing best practices from its member cities.

We expect this functional variation to result in different modes of cooperation and PS. In line with our theoretical reasoning, the monitoring arrangements should be fullyfledged within the CoM, whereas the EC should develop its lobbying activities by tracking the good practices of its members. To control for other organizational and political factors, we select these networks for their similarity of administrative capacities and political support by European institutions. Another similarity is that both networks focus their activities on Europe and are important stakeholders in EU policymaking. Most 
This is a peer-reviewed, accepted author manuscript of the following research article: De Francesco, F., Leopold, L., \& Tosun, J. (2020). Distinguishing policy surveillance from policy tracking: transnational municipal networks in climate and energy governance. Journal of Environmental Policy \& Planning. https://doi.org/10.1080/1523908X.2020.1785280

importantly, we can rule out other contextual factors due to the intricate institutional intertwining of the two networks, which, nonetheless, remain separate initiatives. EC coestablished the predecessor organization of the CoM in 2008 and has assumed a leading role in the central organization of the latter by running the two regional offices of the CoM in Western Europe as well as in Eastern Europe and the South Caucasus. In the case of the European offices, the two networks evidently benefit from shared capacity as several employees, mainly concerned with communication tasks, are responsible for both EC and the CoM.

To derive a detailed description of the two cases, we conducted a systematic analysis of the TMCNs' websites. As the main tools for external communication, these websites are also document repositories, allowing us to examine the TMCNs' information systems in detail. We searched the networks' websites for all resources that either outline the cities' commitments or describe the reporting or monitoring schemes. We also analyzed all strategic documents, press releases, policy reports, and case studies available on the respective websites in order to understand how cities share information within their networks. We complemented this document analysis with an expert interview for both networks.

The ideal types of PS constructed above guided us in the selection of relevant information. We are aware that types are oversimplifications, flattening detailed aspects that emphasize groups' differences more than their commonalities. However, typologies enable us to refine the meaning of a concept like PS by mapping out its dimensions. 
This is a peer-reviewed, accepted author manuscript of the following research article: De Francesco, F., Leopold, L., \& Tosun, J. (2020). Distinguishing policy surveillance from policy tracking: transnational municipal networks in climate and energy governance. Journal of Environmental Policy \& Planning. https://doi.org/10.1080/1523908X.2020.1785280

\section{An empirical assessment of city networks' monitoring activities}

\section{Covenant of Mayors for Climate \& Energy}

CoM cities are obliged to set concrete benchmarks for GHG emission reduction, which must exceed the targets of either the EU's 2020 or 2030 energy strategies. Hence, those targets are of an impact-type nature. They are also encouraged to set individual, contextspecific adaptation targets, e.g., concerning energy security. Therefore, the functional focus of the CoM lies on attaining specific targets and harder forms of soft governance, such as 'naming-and-shaming' approaches.

The type of information that CoM cities must provide on the network's website is, in line with our typology of PS, mainly of a quantitative nature. First, additional to each cities' mitigation targets, they provide quantitative baseline data, e.g., on the amount and sectoral composition of GHG emissions, energy consumption, and energy production. Due to the CoM's periodical reporting requirement, the data collected by the network are longitudinal, allowing for a systematic review of the cities' efforts. The methodology of the emission inventory and baseline data must be made public and observe the guidelines for compiling the Sustainable Energy and Climate Action Plan (SECAP). Hence, objectivity and neutrality of information are ensured. It is also reported on how much of the energy mitigation budget has already been spent. Changes in the total GHG emissions and changes by sectors (e.g., transport or industry), as well as changes in the amount of energy consumption, are compared with the baseline year.

Accordingly, the CoM's approach is mainly based on research and evaluation. The collected data can be used to explain the cities' performances. The validity of their comparative measures is ensured by engaging scholars. Moreover, the CoM employs permanent staff that oversee the data collection. The CoM information system can be 
This is a peer-reviewed, accepted author manuscript of the following research article: De Francesco, F., Leopold, L., \& Tosun, J. (2020). Distinguishing policy surveillance from policy tracking: transnational municipal networks in climate and energy governance. Journal of Environmental Policy \& Planning. https://doi.org/10.1080/1523908X.2020.1785280

accessed through a website that reports aggregate measures of mitigation implementation as well as total expenditure. Such indicators are successively transformed into scores of cities according to their attainment of targets.

Furthermore, the CoM is particularly committed to engaging with experts and EU institutions such as the European Committee of the Regions and the European Environment Agency that are members of this network. The network provides an online data platform which interested researchers can access, enabling the network to encourage scientific output on energy mitigation.

To facilitate implementation of the monitoring scheme, the CoM relies on extensive periodical reporting. After the submission of their initial SECAP no later than two years after adhesion, the members must use a standardized scorecard to self-report on the overall strategy and adaptation and mitigation actions, as well as on information on risks and vulnerabilities. In addition to this, an emission inventory must be provided at least every four years, so that the cities' actual progress can be assessed (CoM, 2016). Published on the respective cities' sites, this inventory includes a set of aggregate and standardized indicators, such as local electricity production or transport, the total expenditure, and reductions in GHG emissions. If a member does not comply with the reporting requirements, CoM can temporarily suspend it from the network ([CoM], n.d.). Suspended cities member's profile on the CoM website is grayed out to mark their status, and they do not appear in the website's search results. Thus, visitors to the website can determine which cities are suspended from the CoM. Suspended member cities are allowed to rejoin as soon as they obey the reporting guidelines, submitting the required monitoring reports or emission inventories. In practice, however, the CoM appears to not make frequent use of this naming-and-shaming strategy. Several cities have not published 
This is a peer-reviewed, accepted author manuscript of the following research article: De Francesco, F., Leopold, L., \& Tosun, J. (2020). Distinguishing policy surveillance from policy tracking: transnational municipal networks in climate and energy governance. Journal of Environmental Policy \& Planning. https://doi.org/10.1080/1523908X.2020.1785280 monitoring reports for more than two years, even though their CoM homepages are still active. Similarly, 25 member cities who joined the initiative before 2016, but have failed to submit an action plan as of May 2019, have not been suspended from the network's website.

The provisions of the CoM follow high standards of openness and transparency. CoM also pays attention to the swift implementation of the measures indicated in the SECAP. Visitors to the website can obtain information on the estimated GHG emissions per sector, compare them to the baseline year, and see the changes in final energy consumption by the various energy carriers. Information on the funds spent on relevant activities increases the accountability of both the individual city governments and of the city network as a whole.

In sum, the CoM's strategy is based on collecting and processing information that publicly benchmarks the performance of the individual cities' efforts to reduce GHG emissions. The reporting requirements of the CoM are demanding and commit cities to targets, strategies, and periodical reporting on their progress. Furthermore, the CoM can rely on harder forms of governance, such as the suspension of members from the network in case of sustained non-compliance. As the CoM is not financed by membership fees, it can be more autonomous than EC in collecting neutral and objective information and in bearing the cost of adopting a naming-and-shaming strategy. The CoM thus represents the ideal type of a PS system that is specialized for safeguarding the progress of cities concerning their pledges, since it creates an environment in which naming and shaming is possible.

\section{Energy Cities}

The EC's goals comprise the dissemination of knowledge among its members as well as 
This is a peer-reviewed, accepted author manuscript of the following research article: De Francesco, F., Leopold, L., \& Tosun, J. (2020). Distinguishing policy surveillance from policy tracking: transnational municipal networks in climate and energy governance. Journal of Environmental Policy \& Planning. https://doi.org/10.1080/1523908X.2020.1785280

lobbying on the political level, instead of the attainment of specific mitigation targets. Since no impact-type pledges are set by the members, naming-and-shaming approaches are not facilitated. The absence of penalizing mechanisms represents a main difference between PS and PT. EC is partially funded by membership fees and therefore in a weaker position to enforce common goals. Harder measures, such as the suspension of networking members, are not facilitated as EC only records the member cities' activities related to climate change mitigation and energy transformation and provides an online database wherein member cities can showcase their policies. Cities can publish descriptive reports on their activities for the promotion and sharing of good practices, as we expected from PT systems. Furthermore, the EC policy database reveals that not all member cities are equally active in reporting their mitigation measures. This confirms the different ways that the CoM and EC monitor their members' activities.

Unlike the CoM, the type of information that EC member cities publish online varies significantly. While cities in the CoM are required to report standardized quantitative data, EC members can choose how to draft their qualitative reports on energy projects.

Therefore, policy actions cannot be compared, and no longitudinal dataset can be constructed from the cities' reports. The qualitative nature of information gathered for the online database confirms our distinction between PS and PT and locates EC clearly towards the latter, which is appropriated to advocacy activities. Due to the lack of comparative data, EC cannot generate scientifically sound knowledge on the impact of cities' climate change policies.

EC's advocacy orientation can be observed beyond their provision of an online platform for sharing cities' policy activities. Based on the submitted reports, the EC 
This is a peer-reviewed, accepted author manuscript of the following research article: De Francesco, F., Leopold, L., \& Tosun, J. (2020). Distinguishing policy surveillance from policy tracking: transnational municipal networks in climate and energy governance. Journal of Environmental Policy \& Planning. https://doi.org/10.1080/1523908X.2020.1785280

secretariat published on how to approach 30 of the most pressing issues that cities face in the light of energy transition. Without being overly academized, as is the case with the CoM publications, this report provides evidence of 'what works' in the development of cities' mitigation strategies.

As with the CoM, the data are mainly provided by city administrations resulting in a low level of comparability and credibility. Since EC members can choose what to report, important drivers of best practices might be overlooked. While CoM has adopted a standardized methodology, EC lacks any reporting guidelines. In line with the typology of PT systems, EC employs permanent staff to facilitate the network's advocacy capacity.

Concerning the engagement of peers, EC is less committed than the CoM. While EC partners with several other networks dedicated to tackling and adapting to climate change (e.g., the Coalition for Energy Savings or the Heat Coalition), the network does not actively motivate actors from academia or the private sector to support the initiative. Moreover, the current partners of EC seem to exhibit less organizational capacity than the institutions which support the CoM. Hence, the degree to which EC engages peers from outside the network is relatively low compared to the CoM. In line with our expectation, peer validation is not essential when the focus of a network is on PT.

Even though both networks rely on self-reporting systems, EC and the CoM again differ to a considerable extent regarding the tools and practices of their reporting systems. CoM members are commited to use a harmonized set of indicators to report on their progress every two years and to update the GHG emission inventory. In contrast, EC members have no formal commitment to report within certain periods or even to report at all. If they choose to do so, there are no prescriptions for which data cities must report nor any standardized templates for reporting, undermining the quality of data collection. 
This is a peer-reviewed, accepted author manuscript of the following research article: De Francesco, F., Leopold, L., \& Tosun, J. (2020). Distinguishing policy surveillance from policy tracking: transnational municipal networks in climate and energy governance. Journal of Environmental Policy \& Planning. https://doi.org/10.1080/1523908X.2020.1785280

Cities thus have high levels of discretion regarding the tracking of their policies. This again reveals the network's advocacy and knowledge-sharing orientation and speaks in favour of categorizing the EC's information system as a PT mechanism.

Concerning the last dimension, openness and transparency, the data provided by the website of Energy cities are less transparent than the Covenant of Mayors'. EC's monitoring system is first and foremost based on the submission of policy reports. Although some reports include quantified effects that specific policies had on climate change mitigation and energy transition, since no standardized methodology for data collection exists, the level of transparency regarding this information is low compared to the CoM's surveillance system. Hence, as expected, it is impossible to benchmark cities according to their performance. We expected to find this level of transparency in PT systems. In sum, EC is significantly closer to the ideal type of a PT system specialized in mapping and sharing best practices.

\section{Summary}

Table 2 summarizes the key dimensions for the networks and alludes to differences and similarities in their monitoring arrangements. The descriptive analysis revealed that we can indeed observe two distinctive modes of cooperation among cities for promoting approaches to solving issues of climate change within energy policy. We found a differentiated use of collected data and comparative analyses. The CoM is clearly consistent with the ideal type of PS which can employ strategies of naming and shaming. This network can go further by suspending the membership of cities that fail to comply with the reporting requirements. By contrast, EC approaches the ideal type of a PT system that ensures mutual learning among members. 
This is a peer-reviewed, accepted author manuscript of the following research article: De Francesco, F., Leopold, L., \& Tosun, J. (2020). Distinguishing policy surveillance from policy tracking: transnational municipal networks in climate and energy governance. Journal of Environmental Policy \& Planning. https://doi.org/10.1080/1523908X.2020.1785280

\section{Implications for EU policy}

What can EU institutions learn from the TMCNs in PS? First, the EU should draw from typologies of collaborative networks based on different modes of policy coordination according to different policy contexts. This variation would allow the EU to gather evidence on the effectiveness of transnational governance and policy evaluation. Second, as a harder mechanism of governance, PS requires a high level of transparency with credible, open and accessible information from participating members as well as the constant engagement of experts, civil society organizations and other TMCNs. Our analysis shows that these are the constitutive elements that harden PS systems based on international pledges and policy targets. Consequently, the EU should provide means for city networks to operate under the necessary level of transparency, which may include increasing the institutional capacity of these organizations. Finally, the experience of the CoM shows that harder forms of commitment to climate change mitigation and energy decarbonization is also possible without a legislative and mandatory framework. Through naming-and-shaming mechanisms, reputational incentives can be more effective than regulatory enforcement based on formal compliance and sanctions. Therefore, the EU may want to support additional initiatives that operate on the basis of this approach.

\section{Conclusions}

In this study, we connected two strands of literature. The first is the literature on polycentric climate governance, which acknowledges the changing institutional landscape of international climate politics. This body of research has witnessed the emergence of actors besides national governments, including regional and local governments and TMCNs (Bansard et al., 2017; Bellinson \& Chu, 2019; Jordan et al., 
This is a peer-reviewed, accepted author manuscript of the following research article: De Francesco, F., Leopold, L., \& Tosun, J. (2020). Distinguishing policy surveillance from policy tracking: transnational municipal networks in climate and energy governance. Journal of Environmental Policy \& Planning. https://doi.org/10.1080/1523908X.2020.1785280

2015; Wolfram et al., 2019). The second strand of literature concentrates on the EU's climate and energy policy frameworks. These contributions have stressed changes in the different frameworks adopted as well as the existence of different modes of governance and their effects on the attainment of policy goals. A more recent approach is provided by the question of how the separate governance modes become modified in order to achieve the intended steering goals. Research on the hardening of soft governance falls into this category (Knodt et al., 2020; Knodt \& Schoenefeld, 2020; Ringel \& Knodt, 2018; Schoenefeld \& Jordan, 2020).

We focused on the question of whether and why TMCNs use more rigorous, harder elements of PS in order to stimulate climate-related policy action and experimentation among its member cities. By examing TMCNs, we can draw lessons on what the governance arrangements of the Energy Union should look like. Relying on concepts stemming from the research on international PS, we showed how to distinguish PS from PT. This analytical framework allowed us to demonstrate that TMCNs are willing to monitor their members' policy initiatives in climate and energy policy, but that differences even exist between institution-led TMCNs. By contrasting the CoM with EC, we observe that the former has adopted a PS system that is based on credible, open and transparent information. Such an information system has allowed the CoM to set policy targets and establish mechanisms of naming and shaming. On the contrary, the longestablished EC has coherently combined advocacy activities with the dissemination of members' best practices, as is typical of networks engaged in strategic urbanism. Therefore, EC does not rely on PS. We maintain that a combination of harder forms of policy monitoring with well-funded institution-led TMCNs could help to propose and implement more ambitious climate action in Europe. 
This is a peer-reviewed, accepted author manuscript of the following research article: De Francesco, F., Leopold, L., \& Tosun, J. (2020). Distinguishing policy surveillance from policy tracking: transnational municipal networks in climate and energy governance. Journal of Environmental Policy \& Planning. https://doi.org/10.1080/1523908X.2020.1785280

Future research can advance this line of inquiry in theoretical and empirical ways. We showed that among institution-led TMCNs, differences exist in the ways policy coordination is achieved. Our expectations concentrated on the functional purpose of TMCNs and their sources of funding. Consequently, from a theoretical perspective, future research could invest in developing a more comprehensive argument about how different features of institution-led TMCNs can lead to different approaches to PS. Another promising theoretical perspective for future research could integrate the conceptualizations of policy learning into an analysis on TMCNs by assessing which policy evaluation systems are more effective in stimulating policy learning. 
This is a peer-reviewed, accepted author manuscript of the following research article: De Francesco, F., Leopold, L., \& Tosun, J. (2020). Distinguishing policy surveillance from policy tracking: transnational municipal networks in climate and energy governance. Journal of Environmental Policy \& Planning. https://doi.org/10.1080/1523908X.2020.1785280

\section{References}

Aldy, J.E. (2014). The Crucial Role of Policy Surveillance in International Climate Policy. Climatic Change, 126(3-4), 279-292.

Aldy, J.E. (2017). Policy Surveillance in the G-20 Fossil Fuel Subsidies Agreement: Lessons for Climate Policy. Climatic Change, 144(1), 97-110.

Aldy, J.E., \& Pizer, W.A. (2016). Alternative Metrics for Comparing Domestic Climate Change Mitigation Efforts and the Emerging International Climate Policy Architecture. Review of Environmental Economics and Policy, 10(1), 3-24.

Bansard, J.S., Pattberg, P.H., \& Widerberg, O. (2017). Cities to the rescue? Assessing the performance of transnational municipal networks in global climate governance. International Environmental Agreements: Politics, Law and Economics, 17(2), 229246.

Bellinson, R., \& Chu, E. (2019). Learning pathways and the governance of innovations in urban climate change resilience and adaptation. Journal of Environmental Policy \& Planning, 21(1), 76-89.

Bulkeley, H., \& Betsill, M.M. (2013). Revisiting the urban politics of climate change. Environmental Politics, 22(1), 136-154.

Chriqui, J.F., \& Eyler, A.A. (2016). Public Policy Tracking and Surveillance. Assessing Adoption and Content for Advocacy and Evaluation Purposes. In A.A. Eyler, J.F. Chriqui, S. Moreland-Russell, \& R.C. Brownson (Eds.), Prevention, Policy, and Public Health (pp. 291-302). New York: Oxford University Press.

Chriqui, J.F., O'Connor, J.C., \& Chaloupka, F.J. (2011). What gets measured, gets changed: evaluating law and policy for maximum impact. The Journal of Law, 
This is a peer-reviewed, accepted author manuscript of the following research article: De Francesco, F., Leopold, L., \& Tosun, J. (2020). Distinguishing policy surveillance from policy tracking: transnational municipal networks in climate and energy governance. Journal of Environmental Policy \& Planning. https://doi.org/10.1080/1523908X.2020.1785280

Medicine \& Ethics : a Journal of the American Society of Law, Medicine \& Ethics, 39, 21-26.

CoM. (n.d.). The Covenant of Mayors for Climate and Energy. Retrieved from WwW.covenantofmayors.eu/IMG/pdf/covenantofmayors_text_en.pdf

CoM. (2016). The Covenant of Mayors for climate and energy reporting guidelines (July 2016). Retrieved from www.covenantofmayors.eu/IMG/pdf/Covenant_ReportingGuidelines.pdf

Dunlop, C.A., \& Radaelli, C.M. (2013). Systematising Policy Learning: From Monolith to Dimensions. Political Studies, 61(3), 599-619.

Dunlop, C.A., \& Radaelli, C.M. (2018). The lessons of policy learning: types, triggers, hindrances and pathologies. Policy \& Politics, 46(2), 255-272.

Energy Cities. (2015). Energy Cities' contribution to the Public consultation on EIB approach to supporting climate action. Retrieved from http://www.energycities.eu/IMG/pdf/150316_energycities_eib_climate_action_consultation.pdf

Esty, D.C., \& Karpilow, Q. (2019). Harnessing Investor Interest in Sustainability: The Next Frontier in Environmental Information Regulation. Yale Journal on Regulation, 36(2), 625-692.

Fünfgeld, H. (2015). Facilitating local climate change adaptation through transnational municipal networks. Current Opinion in Environmental Sustainability, 12, 67-73. Gordon, D.J. (2016). The Politics of Accountability in Networked Urban Climate Governance. Global Environmental Politics, 16(2), 82-100.

Jordan, A.J., Huitema, D., Hildén, M., van Asselt, H., Rayner, T.J., Schoenefeld, J.J., . . Boasson, E.L. (2015). Emergence of polycentric climate governance and its future prospects. Nature Climate Change, 5(11), 977-982. 
This is a peer-reviewed, accepted author manuscript of the following research article: De Francesco, F., Leopold, L., \& Tosun, J. (2020). Distinguishing policy surveillance from policy tracking: transnational municipal networks in climate and energy governance. Journal of Environmental Policy \& Planning. https://doi.org/10.1080/1523908X.2020.1785280

Kern, K. (2018). Cities as leaders in EU multilevel climate governance: embedded upscaling of local experiments in Europe. Environmental Politics, 28(1), 125-145.

Knodt, M., Ringel, M., \& Müller, R. (2020). Variations of “Harder” Soft Governance in European Energy Policy [forthcoming]. Journal of Environmental Policy \& Planning.

Knodt, M., \& Schoenefeld, J.J. (2020). Harder soft governance in European climate and energy policy: Following a new trend? [forthcoming]. Journal of Environmental Policy \& Planning.

Lee, T., \& Jung, H.Y. (2018). Mapping city-to-city networks for climate change action: Geographic bases, link modalities, functions, and activity. Journal of Cleaner Production, 182, 96-104.

Lehtonen, M. (2020). Harder governance built on soft foundations: experience from OECD peer reviews [forthcoming]. Journal of Environmental Policy \& Planning. Nagorny-Koring, N.C. (2018). Leading the way with examples and ideas? Governing climate change in German municipalities through best practices. Journal of Environmental Policy \& Planning, 21(1), 46-60.

Ringel, M., \& Knodt, M. (2018). The governance of the European Energy Union: Efficiency, effectiveness and acceptance of the Winter Package 2016. Energy Policy, 112, 209-220.

Schelling, T.C. (2002). What Makes Greenhouse Sense? Foreign Affairs, 81(2), 2-9. Schoenefeld, J.J., Hildén, M., \& Jordan, A.J. (2018). The challenges of monitoring national climate policy: learning lessons from the EU. Climate Policy, 18(1), 118128. 
This is a peer-reviewed, accepted author manuscript of the following research article: De Francesco, F., Leopold, L., \& Tosun, J. (2020). Distinguishing policy surveillance from policy tracking: transnational municipal networks in climate and energy governance. Journal of Environmental Policy \& Planning. https://doi.org/10.1080/1523908X.2020.1785280

Schoenefeld, J.J., \& Jordan, A.J. (2020). Towards Harder Soft Governance? Monitoring Climate Policy in the EU [forthcoming]. Journal of Environmental Policy \& Planning.

Terman, R., \& Voeten, E. (2018). The relational politics of shame: Evidence from the universal periodic review. The Review of International Organizations, 13(1), 1-23.

Tosun, J., \& Leopold, L. (2019). Aligning Climate Governance with Urban Water Management: Insights from Transnational City Networks. Water, 11(4), 701. van der Heijden, J. (2018). City and Subnational Governance: High ambitions, innovative instruments and polycentric collaborations. In A.J. Jordan, D. Huitema, H. van Asselt, \& J. Forster (Eds.), Governing Climate Change: polycentricity in action (pp. 81-96). Cambridge: Cambridge University Press.

van Erp, J. (2011). Naming and Shaming in Regulatory Enforcement. In C. Parker \& V. Nielsen (Eds.), Explaining Compliance (pp. 322-342). Cheltenham: Edward Elgar Publishing.

Wolfram, M., van der Heijden, J., Juhola, S., \& Patterson, J. (2019). Learning in urban climate governance: concepts, key issues and challenges. Journal of Environmental Policy \& Planning, 21(1), 1-15. 
Table 1. Summary of the dimensions of information systems for institution-led TMCNs

\begin{tabular}{|c|c|c|}
\hline $\begin{array}{l}\text { Dimensions of } \\
\text { information system }\end{array}$ & $\begin{array}{l}\text { Policy surveillance of } \\
\text { pledges and targets }\end{array}$ & $\begin{array}{l}\text { Policy tracking for } \\
\text { mapping good practices }\end{array}$ \\
\hline Functional focus & $\begin{array}{l}\text { - Compliance with } \\
\text { international agreements } \\
\text { and commitments } \\
\text { - Naming and shaming }\end{array}$ & $\begin{array}{l}\text { - Advocacy through the } \\
\text { dissemination of good } \\
\text { practices } \\
\text { - Construction of common } \\
\text { discourse and cognitive } \\
\text { frame of how to solve } \\
\text { environmental issues }\end{array}$ \\
\hline Type of information & Quantitative & Qualitative \\
\hline $\begin{array}{l}\text { Research/advocacy } \\
\text { orientation }\end{array}$ & $\begin{array}{l}\text { Oriented towards research } \\
\text { and evaluation }\end{array}$ & $\begin{array}{l}\text { Oriented towards } \\
\text { advocacy and reporting }\end{array}$ \\
\hline Credibility of information & $\begin{array}{l}\text { Neutral information based } \\
\text { on independent expertise }\end{array}$ & Information from cities \\
\hline Engagement of peers & High level of peer review & Low level of peer review \\
\hline Tools for policy learning & $\begin{array}{l}\text { Comparative measures, } \\
\text { and annual reporting with } \\
\text { standardized reports }\end{array}$ & $\begin{array}{l}\text { Self-reporting of best } \\
\text { practices }\end{array}$ \\
\hline $\begin{array}{l}\text { Openness and } \\
\text { transparency }\end{array}$ & $\begin{array}{l}\text { Data available on websites } \\
\text { for easy dissemination of } \\
\text { comparative assessment } \\
\text { and benchmarking }\end{array}$ & $\begin{array}{l}\text { Public access to original } \\
\text { data sources but not } \\
\text { comparative assessment } \\
\text { and benchmarking }\end{array}$ \\
\hline $\begin{array}{l}\text { Expectation: evolution } \\
\text { phases of transnational } \\
\text { cities networks }\end{array}$ & $\begin{array}{l}\text { Networks engaged with } \\
\text { policy targets and pledges }\end{array}$ & Strategic urbanism \\
\hline $\begin{array}{l}\text { Expectation: funding } \\
\text { sources of institution-led } \\
\text { networks }\end{array}$ & $\begin{array}{l}\text { Substantially funded by a } \\
\text { single external stakeholder }\end{array}$ & $\begin{array}{l}\text { Multiple funding sources, } \\
\text { including membership fees }\end{array}$ \\
\hline
\end{tabular}

Note: Adapted from Chriqui et al. (2011). 
Table 2: Overview of the city networks' cooperation

\begin{tabular}{|c|c|c|}
\hline Dimensions & Covenant of Mayors & Energy Cities \\
\hline Focus & $\begin{array}{l}\text { - CoM cities provide an action plan and } \\
\text { data on how well they perform in } \\
\text { achieving their targets } \\
\text { - CoM website gives accessible } \\
\text { information on each city's targets and } \\
\text { progress; cities are awarded for their } \\
\text { progress }\end{array}$ & $\begin{array}{l}\text { - EC provides a collection } \\
\text { of projects, reports and } \\
\text { case studies from member } \\
\text { cities' activities and action } \\
\text { plans } \\
\text { - EC members don't } \\
\text { commit to any specific } \\
\text { targets, a context for } \\
\text { 'naming and shaming' is } \\
\text { not facilitated }\end{array}$ \\
\hline $\begin{array}{l}\text { Type of } \\
\text { information }\end{array}$ & $\begin{array}{l}\text { - website provides quantitative and } \\
\text { comparative data on, e.g., implementation } \\
\text { progress, budget spent, and GHG } \\
\text { emissions }\end{array}$ & $\begin{array}{l}\text { - predominantly qualitative } \\
\text { - few reports provide } \\
\text { numbers on how effective } \\
\text { given initiatives were; no } \\
\text { comparative data }\end{array}$ \\
\hline $\begin{array}{l}\text { Research } \\
\text { vs. } \\
\text { advocacy } \\
\text { orientation }\end{array}$ & $\begin{array}{l}\text { - website compares current data on, e.g., } \\
\text { GHG emissions or energy production } \\
\text { against baseline values } \\
\text { - motivates researchers }\end{array}$ & $\begin{array}{l}\text { - reports and case studies } \\
\text { are mostly designed to } \\
\text { stimulate learning } \\
\text { - the EC secretariat } \\
\text { publishes comparative } \\
\text { studies, e.g., on cities' } \\
\text { actions which might have } \\
\text { the same effect }\end{array}$ \\
\hline $\begin{array}{l}\text { Credibility } \\
\text { of } \\
\text { information }\end{array}$ & $\begin{array}{l}\text { - data come from the cities; but the } \\
\text { methodology for compiling the action } \\
\text { plan, conducting the risk and vulnerability } \\
\text { assessment and for measuring the GHG } \\
\text { emissions are standardized }\end{array}$ & $\begin{array}{l}\text { - reports on specific } \\
\text { policies come from the } \\
\text { member cities; no neutral } \\
\text { validation }\end{array}$ \\
\hline $\begin{array}{l}\text { Engagement } \\
\text { of peers }\end{array}$ & $\begin{array}{l}\text { - engagement of peers from academia and } \\
\text { institutions such as the CoR and the EEA }\end{array}$ & $\begin{array}{l}\text { - no broad engagement of } \\
\text { peers }\end{array}$ \\
\hline $\begin{array}{l}\text { Tools and } \\
\text { practices }\end{array}$ & $\begin{array}{l}\text { - comparative measures } \\
\text { - periodical reporting (each } 2 \text { years) } \\
\text { - standardized methodology }\end{array}$ & $\begin{array}{l}\text { - cities decide on what they } \\
\text { report } \\
\text { - no comparative measures } \\
\text { - no standardized reports } \\
\text { - no obligation to report } \\
\text { periodically }\end{array}$ \\
\hline $\begin{array}{l}\text { Openness } \\
\text { and } \\
\text { transparency }\end{array}$ & $\begin{array}{l}\text { - website provides a multitude of } \\
\text { accessible indicators and is very clear and } \\
\text { overseeable }\end{array}$ & $\begin{array}{l}\text { - usually no verifiable } \\
\text { sources }\end{array}$ \\
\hline
\end{tabular}

Note: Own elaboration. 